\title{
A Review of Biomarkers for Alzheimer's Disease in Down Syndrome
}

\author{
Ni-Chung Lee · Yin-Hsiu Chien · Wuh-Liang Hwu
}

Received: March 3, 2017

(C) The Author(s) 2017. This article is an open access publication

\section{ABSTRACT}

Down syndrome (Trisomy 21; DS) is a unique disease known to be associated with early-onset Alzheimer's disease (AD). The initial presentation of $\mathrm{AD}$ in $\mathrm{DS}$ is usually difficult to recognize, owing to the underlying intellectual disabilities. Using biomarkers as a prediction tool for detecting $\mathrm{AD}$ in at-risk people with $\mathrm{DS}$ may benefit patient care. The objective of this review is to discuss the utility of biomarkers in DS on the basis of the pathophysiology of the disease and to provide an update on recent studies in this field. Only through the comprehensive assessment of clinical symptoms, imaging studies, and biomarker analyses can people with DS who are at risk for AD be diagnosed early. Studies for biomarkers of AD in DS have focused on the common pathophysiology of $\mathrm{AD}$ in people with DS and in the general population. The most extensively studied biomarkers are amyloid and tau. Owing to the nature of amyloid precursor protein overproduction in DS,

Enhanced content To view enhanced content for this article go to http://www.medengine.com/Redeem/ CAD8F06039796B6E.

Ni-ChungLee $(\bowtie) \cdot$ Yin-HsiuChien

Wuh-LiangHwu

Department of Medical Genetics and Pediatrics, National Taiwan University Hospital and National

Taiwan University College of Medicine, Taipei,

Taiwan

e-mail: ncleentu@ntu.edu.tw the baseline $\beta$-amyloid (A $\beta)$ plasma levels are higher than those in controls. Hence, the changes in $A \beta$ are considered to be a predictive marker for $\mathrm{AD}$ in $\mathrm{DS}$. In addition, other markers related to telomere length, neuroinflammation, and methylation have been investigated for their correlation with $\mathrm{AD}$ progression. Future studies including different ethnic groups may be helpful to collect sufficient data to monitor drug safety and efficacy, stratify patients at risk for $\mathrm{AD}$, and quantify the benefit of treatment.

Keywords: Alzheimer's disease; Amyloid; Biomarker; Down syndrome; Tau

\section{INTRODUCTION}

Down syndrome (DS) is the most common aneuploidy associated with intellectual disability, with an incidence of approximately 1 in 800 live births $[1,2]$. Children with DS often have multi-systemic manifestations, including intellectual disabilities, short stature, facial dysmorphism, congenital heart disease, thyroid dysfunction, leukemia, and various other congenital malformations [3]. With improvements in medical care, the life expectancy of this cohort has increased to the fifties and sixties [4]. People with DS who live into adulthood face additional problems other than those occurring in childhood. A general acceleration of the 
aging process usually occurs starting at 30 years of age involving premature menopause, presbycusis, alopecia, premature graying of hair, Alzheimer's disease (AD), congestive heart failure, atherosclerosis, diabetes, hypercholesterolemia, autoimmune disease hypertension, and cataracts [5-8]. Among the clinical presentations of accelerated aging, $\mathrm{AD}$ is the most significant. The prevalence of $\mathrm{AD}$ among patients with DS increases from $8 \%$ in the age range of $35-49$ years to $55 \%$ in the age range of $50-59$ years and $75 \%$ above the age of 60 years [9], thus further highlighting the importance of $\mathrm{AD}$ in DS. This article is based on previously conducted studies and does not describe any new studies on humans or animal subjects performed by any of the authors.

\section{Pathophysiology of Alzheimer's Disease in Down Syndrome}

The neuropathological changes in DS with $A D$ have been described as being similar to those in the general population with AD [10]. However, the timing of the amyloid deposition occurs decades earlier [11]. Postmortem DS brains have been reported to show neurofibrillary tangles, cerebrovascular pathology, white matter pathology, oxidative damage, neuroinflammation, and neuron loss [12-15]. On the basis of the above observations, a multifactorial hypothesis explaining the pathophysiology of $\mathrm{AD}$ in DS, in which the two diseases are linked by the amyloid theory, cholesterol metabolism, oxidative stress, immune response, amyloid precursor protein (APP) processing and clearance, and neuroinflammation, has been proposed $[16,17]$. This hypothesis suggests that the link between these two diseases indicates a common etiological pathway.

\section{Amyloid and Related Theories}

After the discovery of $\beta$-amyloid $(A \beta)$ as the major constituent of amyloid plaques, the APP gene, located on chromosome 21 , was considered the key component in the amyloid cascade hypothesis [16]. The accumulation of $A \beta$ in the brains of DS patients may be explained by the hypothesis of the "gene dosage effect". In a DS fetal brain, the expression of APP genes is 1.6 times higher than that in a euploid brain [18]. Overexpression of APP contributes to the accumulation of diffuse, extracellular deposits of $A \beta$ in the brain during the second and third decades of life in DS patients [6]. Subsequently, formation of fibrillar plaques by the end of the fourth decade has been observed [19]. Neurofibrillary degeneration results in impaired neuron function and eventual cell destruction, with patterns similar to that in AD [6]. Recently, researchers have suggested that the neurotoxicity of $A \beta$ comes directly from the induction of oxidative stress and indirectly from the activation of microglia [9]. According to the evidence suggesting that oxidative stress and energy depletion induce intracellular accumulation of $A \beta$, alterations in mitochondrial energy metabolism and reactive oxygen species (ROS) production might be involved in the pathogenesis of neuro-degeneration in DS [20-22]. However, the location of $A \beta$ deposition is different between normal subjects and those with DS. The $A \beta$ deposits in early onset $A D$ begin in the basal cortex, whereas $A \beta$ deposits in DS occur in the hippocampus $[16,23]$. This observation has been explained by differences in the aggregation kinetics of $A \beta$ in DS due to the higher concentration of the $A \beta$ peptide [16]. In addition, the overexpression of the APP gene as well as factors involved in APP gene expression (ETS2), post-translational modification (SUMO3, DYRK1A, SNC27, and miR-155), and APP protein processing and clearance (PICALM, SORL1, $B A C E 1$, and $B A C E 2)$ are considered to modify the aggregation and deposition of $A \beta$ plaques, thus further affecting the age of onset of $\mathrm{AD}$ in DS [16, 24-30].

The formation of neurofibrillary tangles is correlated with cognitive decline $[16,31]$. In addition to tau, other genes involved in neurofibrillary tangle formation in $\mathrm{AD}$ have been proposed on the basis of studies in the general population. The APOE genotype may affect the development of cognitive abilities that tend to be preserved in early stages of AD in DS [32]. For example, the $A P O E \varepsilon 4$ polymorphism has been demonstrated to be significantly associated with $\mathrm{AD}$ and DS [33, 34]. Furthermore, ESR2 rs4986938 allele C and CYP19 rs1870049 
heterozygous $(\mathrm{C} / \mathrm{T})$ have been reported $[33,35,36]$.

\section{Neuroinflammation}

Approximately 12 genes involved in inflammation are located on chromosome 21 (CXADR, ADAMTS1, ADAMTS5, TIAM1, SOD1, IFNAR1, IFNAR2, IFNGR2, RIPK4, CBS, S1OOB, and PRMT2) [37]. The triplication of these genes is considered to affect the inflammatory response to stimuli in microglia/macrophages [37]. Markers for microglia activation, including M2a (CHI3L3, LI-Ra), M2b (CD86), and M2c (TGFB), are elevated in the brains of DS subjects [38], thus resulting in a neurotoxic environment that causes neuronal damage. Furthermore, chromosome 21 carries 299 long non-coding genes and 29 microRNAs, and these microRNAs may also contribute to the onset of dementia in DS [39]. Researchers have hypothesized that the abnormal expression of microRNA (miR-21, miR-103a-1, miR-13a-2, miR-107, miR-9, miR-34, miR-266, miR-101, miR-124, and miR-34b/c) may play a crucial role in the pathological process of $\mathrm{AD}[40,41]$.

\section{Diagnosis of Alzheimer's Disease in Down Syndrome}

The diagnosis of $\mathrm{AD}$ in $\mathrm{DS}$ is challenging because people with DS already have an intellectual disability that hampers the clinical presentation of cognitive decline. Thus, the routine evaluation batteries used in $\mathrm{AD}$, such as the Mini-Mental State Exam (MMSE), are not applicable for people with DS. Assessing DS in people at a very early stage of $\mathrm{AD}$ is more difficult, because the most commonly observed initial changes in DS with AD are usually subtle rather than the cognitive decline or changes in activities of daily living (ADLs) associated with $\mathrm{AD}$ in the general population [42, 43]. Before the diagnosis of $\mathrm{AD}$, people with $\mathrm{DS}$ may present with behavioral/mood changes for a long time; these changes are usually defined as behavioral and psychological symptoms in dementia (BPSD) [42, 44]. BPSD may present with various behavior and psychological symptoms, including activity disturbance, affective disturbance, apathy, isolation, depression, agitation, aggressiveness, anxiety, phobias, diurnal rhythm disturbance, sleep disorders, psychosis, hallucination, paranoia, delusions, appetite and eating abnormalities, disinhibition, and euphoria [42]. However, the clinical diagnosis of BPSD is also challenging because of the underlying intellectual disability, and the prediction of the transformation of BPSD into dementia is also difficult. In this situation, use of other tools, such as clinical assessment tools, neuroimaging, or biomarkers, to evaluate the pathological changes of $\mathrm{AD}$ in $\mathrm{DS}$ may be an alternative.

The tools used for the clinical assessment of $\mathrm{AD}$ in people with $\mathrm{DS}$ must be different from those used for $\mathrm{AD}$ in the general population, owing to the underlying intellectual disability. A variety of testing batteries have been reported to evaluate changes in DS, including the Adaptive Behavior Dementia Questionnaire (ABDQ), the Dementia Scale for Down Syndrome (DSDS), the Dementia Screening Questionnaire for Individuals with Intellectual Disabilities (DSQIID), the Dementia Questionnaire for Mentally Retarded Persons (DMR), and the recently developed Rapid Assessment for Developmental Disabilities (RADD) [45-49]. These questionnaires evaluate functional changes by considering their baseline function levels and then quantifying the degree of functional change. Further neuropsychological assessments for cognitive decline are recommended when patients test positive in this form of report. After the functional decline is recognized, a further imaging evaluation, such as with magnetic resonance imaging (MRI) and/or position emission tomography (PET), may be correlated with the clinical observations.

The amyloid load measured by PET, for example, the Pittsburgh compound B PET (PiB PET), has been used in the assessment of AD in the general population [50]. In DS, the accumulation of amyloid by PiB PET and Florbetaben F18 PET has also been demonstrated [51-53]. In contrast to the observation in the general population, the amyloid deposition in people with DS was first found in the striatum, followed by the rostral prefrontal-cingulo-parietal region, the caudal frontal, rostral temporal, 
primary sensorimotor and occipital regions, and then the medio-temporal regions and other basal ganglia, and the deposition occurs earlier than in the general population $[17,51,53,54]$. Whether the PET imaging results correlate with cognitive function in adults with DS remains controversial $[17,54]$. This method provides a way to identify risk in conjunction with other clinical observations, as well as biomarkers, as proposed in $\mathrm{AD}$ in the general population $[16,52,55]$. In addition, PET studies of glucose metabolism can also be used to identify $A D$ changes in DS, as well as to provide evidence of brain atrophy [56]. One critical future direction would be to perform longitudinal studies in patients starting from an original baseline before 40 years of age, and to use DS patients as a target group for pre-clinical anti-AD drug therapy, because of the high incidence of disease after the age of 40 .

\section{Biomarkers for the Detection of AD in DS}

Biomarkers have been reported to be used not only to diagnose but also to follow up on $\mathrm{AD}$ progress in the general population [17]. The pattern of biomarker changes in $\mathrm{AD}$ in $\mathrm{DS}$ have been considered to be similar to those in $\mathrm{AD}$ [57]. The initial study of AD in DS measured biomarkers (amyloid and tau) in cerebrospinal fluid (CSF) $[58,59]$. Owing to the nature of APP overproduction in DS, the baseline plasma levels of $A \beta 1-40$ and $A \beta 1-42$ and the $A \beta 1-40 /$ A $\beta 1-40$ ratio are higher than those in control [60-64]. A positive correlation of tau and a negative correlation of A $\beta 1-42$ have been reported with age [58]. Subsequently, a method for the detection of plasma amyloid (A $\beta-40$ and $A \beta-42$ ) was developed, and several studies have documented correlations of the changes in amyloid in DS with AD (Table 1) [60, 62, 65-70]. The majority of the reports have concluded that higher levels of $A \beta 1-42$ or the $A \beta 1-42 / A \beta 1-40$ ratio are associated with the onset of $\mathrm{AD}$ in $\mathrm{DS}$ $[62,70,71]$. However, the results in the plasma are opposite from those in the CSF, as CSF A $\beta 1-42$ levels have been consistently reported to be lower than control levels, as determined through different testing methods [58, 72, 73].
The inconsistency between the plasma and CSF results remains a puzzle. To correlate these results with imaging findings, Rafii et al. have demonstrated a greater hippocampal atrophy with a greater amyloid load and an inverse relationship between amyloid load and regional glucose metabolism [57]. However, the cognitive and functional measures do not correlate with the amyloid load but instead correlate with the regional FDG PET [57]. In addition to $A \beta 1-40$ and $A \beta 1-42$, other peptides from $\beta$-amyloid have been studied. Portelius et al. have reported higher levels of $\mathrm{A} \beta 1-28$ and $\mathrm{A} \beta \mathrm{X}-40$ and lower levels of $\mathrm{sAPP} \alpha$ and $\mathrm{SAPP} \beta$ in the CSF of DS subjects compared with healthy controls [73, 74]. For tau protein, increased total tau (T-tau) has been reported in CSF [58, 74]. Because of the small amount of protein in the blood, tau levels were difficult to measure from peripheral blood until the development of the immunomagnetic reduction (IMR) method [53]. Through this method, we have observed a higher baseline tau protein level in people with DS with a negative correlation with functional ability [71]. This result may be explained by the burn-out phenomenon that is also seen in $\mathrm{AD}$ in the general population [55, 71, 75].

In addition to amyloid and tau, several biomarkers have been studied in DS in recent years. Compared with healthy controls, people with DS have been reported to have higher levels of ProNGF, MMP-1, MMP-3, MMP-9, TNF-a, IL-6, IL-10, and $S$-adenosylhomocysteine $(\mathrm{SAH})$, a lower SAM/SAH (S-adenosylmethionine/S-adenosylhomocysteine) ratio and $\mathrm{CpG}$ methylation percentage, and lower levels of amyloid precursor-like protein 1 (APLP1) peptides (APL1 $\beta 25$, APL1 $\beta 27$, and APL1 $\beta 28$ ) and CSF Orexin-A [63, 73, 76]. A lower serum 3-methoxy-4-hydroxyphenylglycol (MHPG) level and shortening of the telomere length predicts the conversion of AD into DS [77, 78]. With the combination of amyloid and inflammatory markers, these biomarkers may be strong predictors of cognitive deterioration [76]. We believe that, with the launch of the DS biomarker initiative project [57], more markers will be identified in the near future to aid in predicting the occurrence of $\mathrm{AD}$ in $\mathrm{DS}$. 


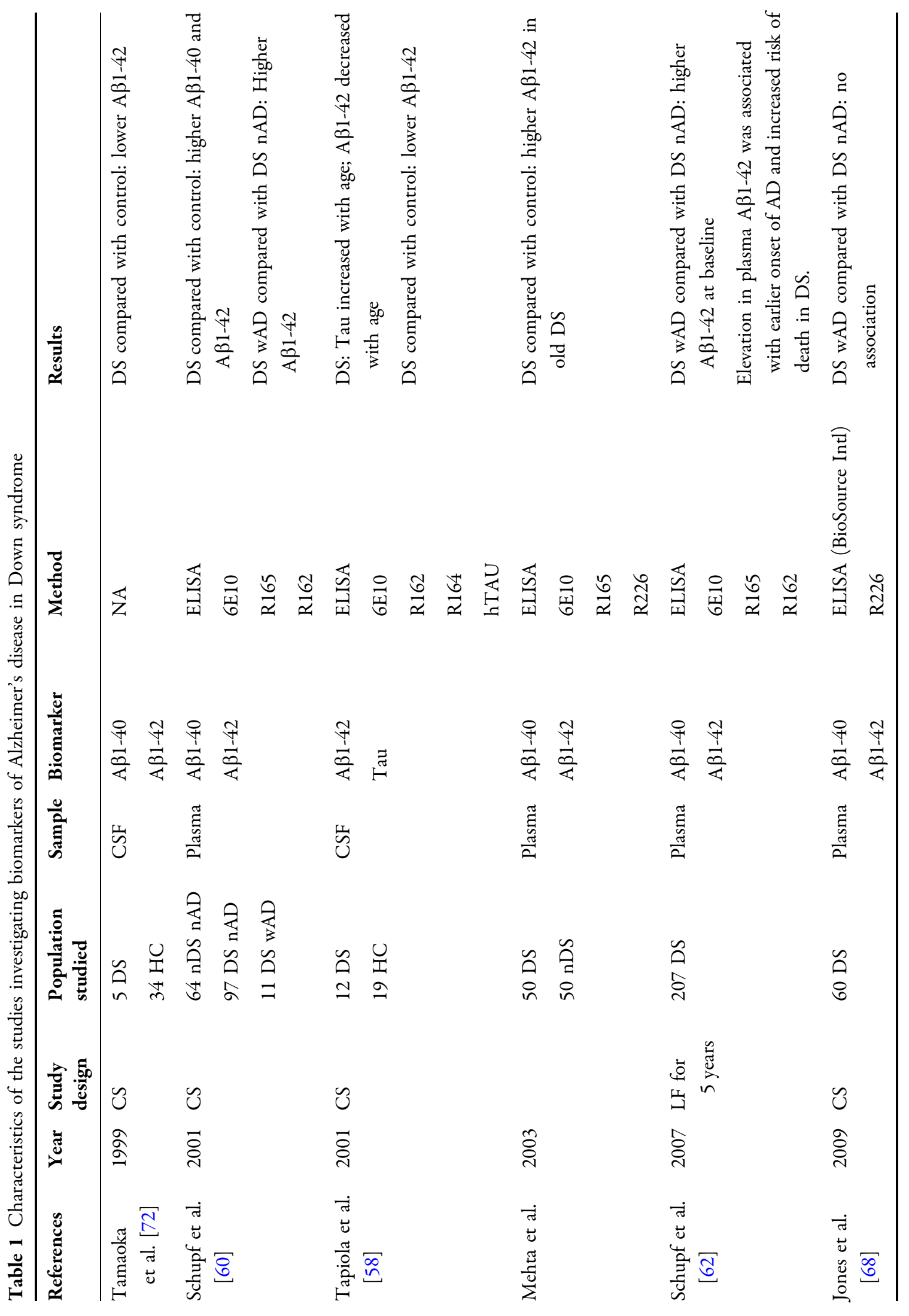




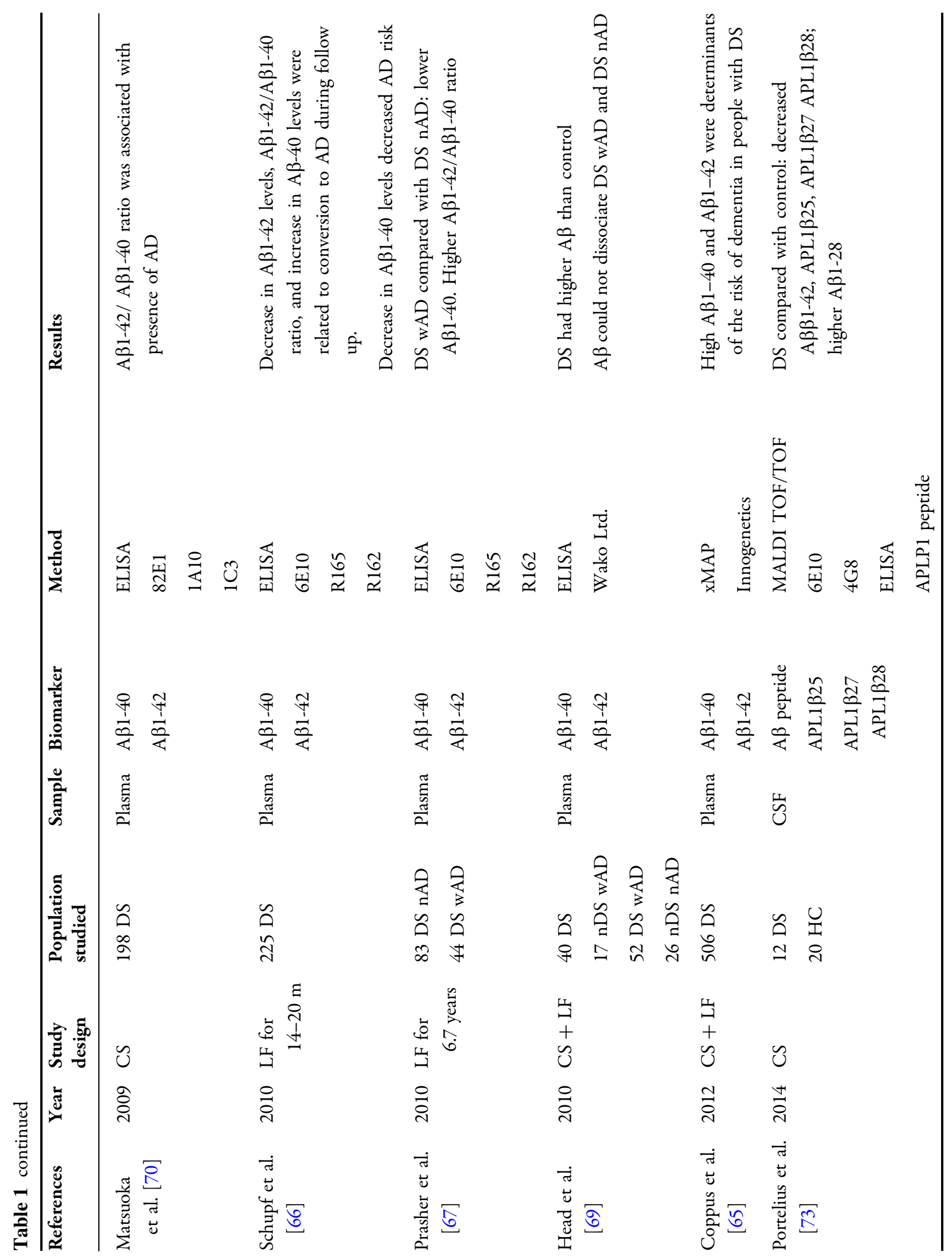




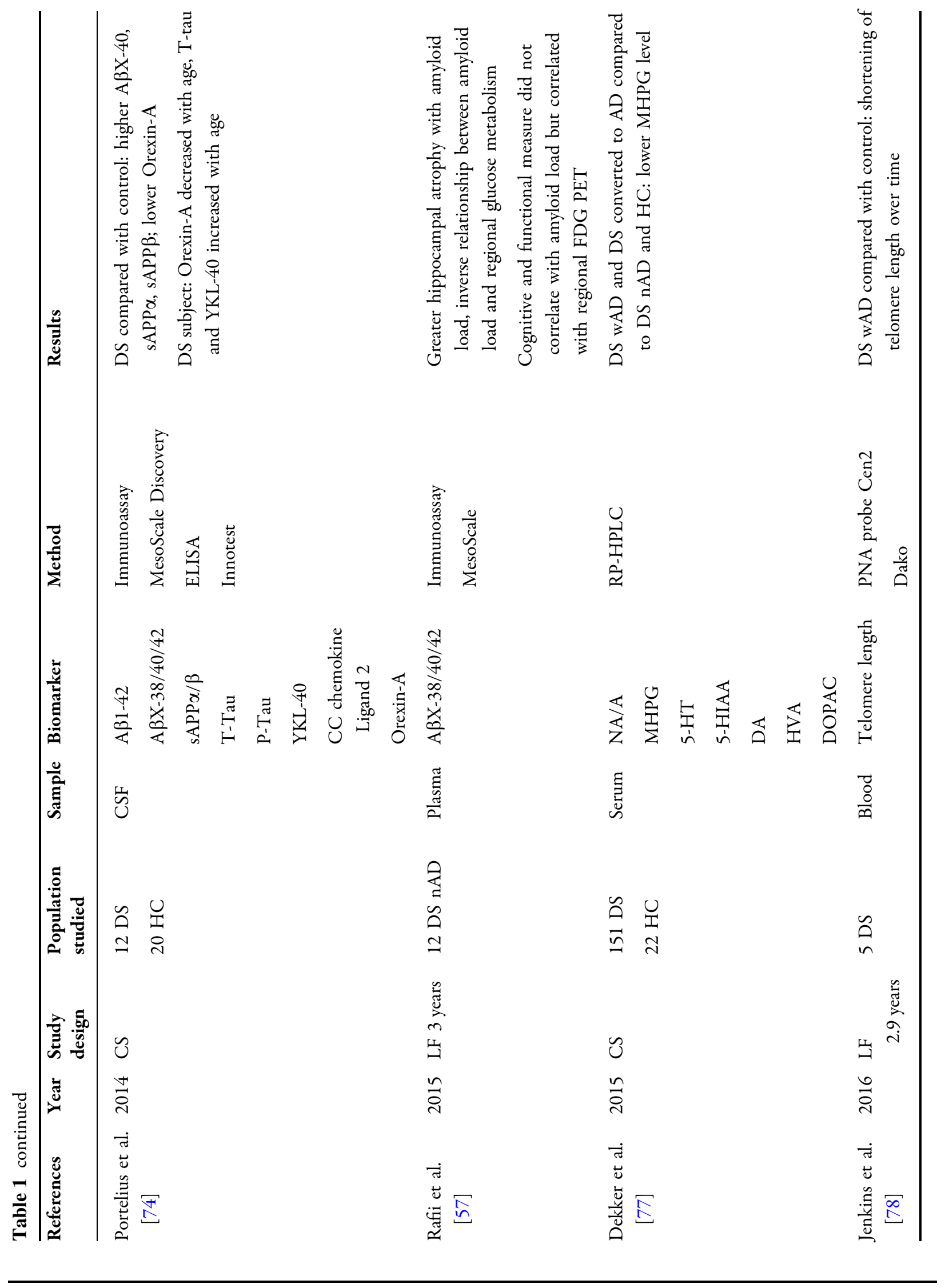




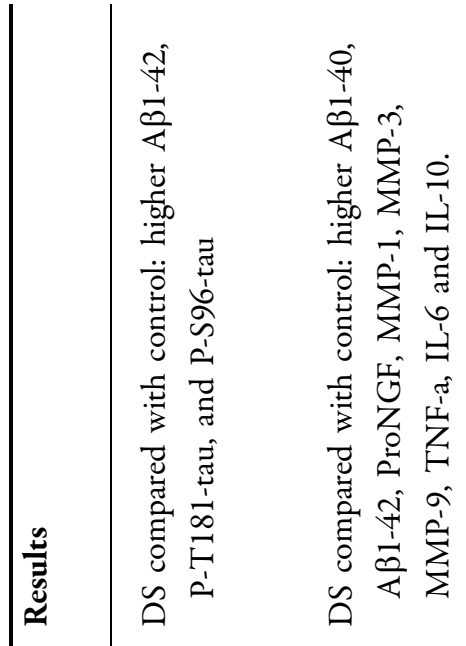

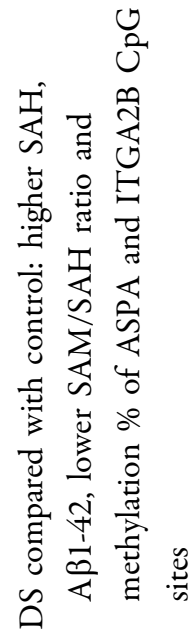

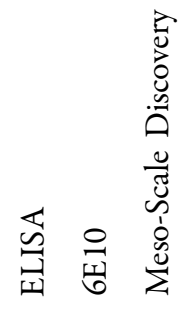

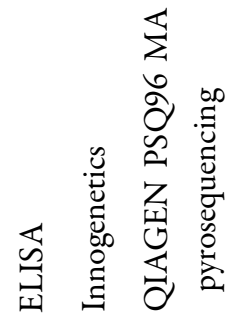

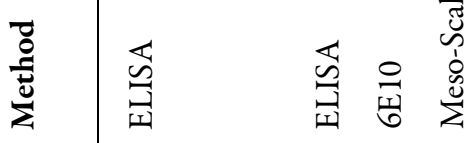
$\stackrel{\hat{\Sigma}}{\dot{1}}$

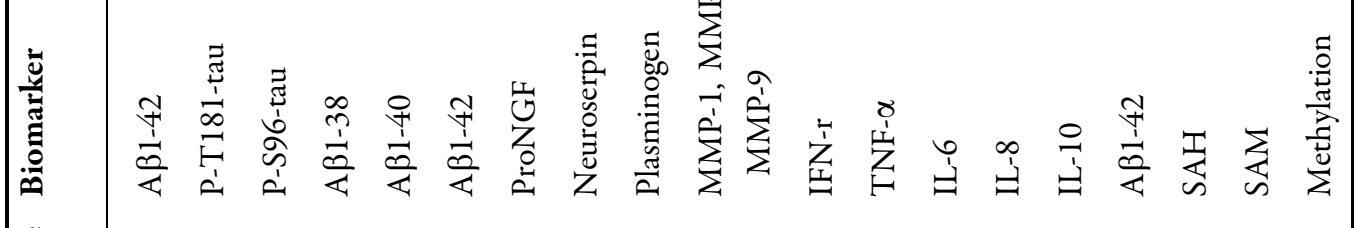

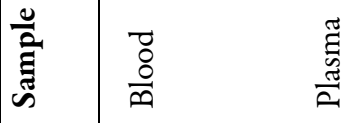

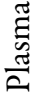

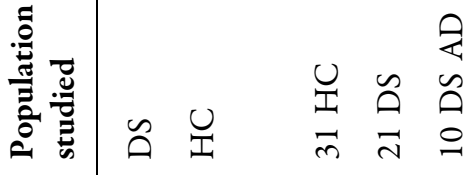
$\frac{\bar{v}}{v}$

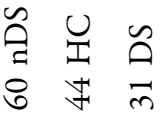

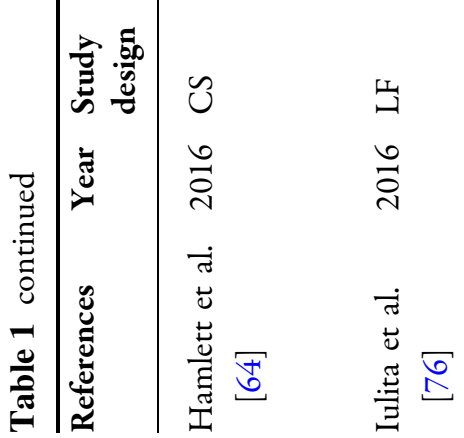

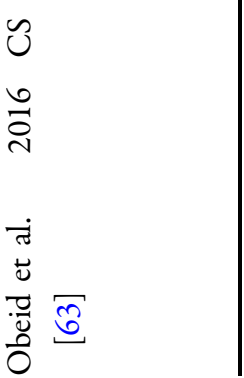




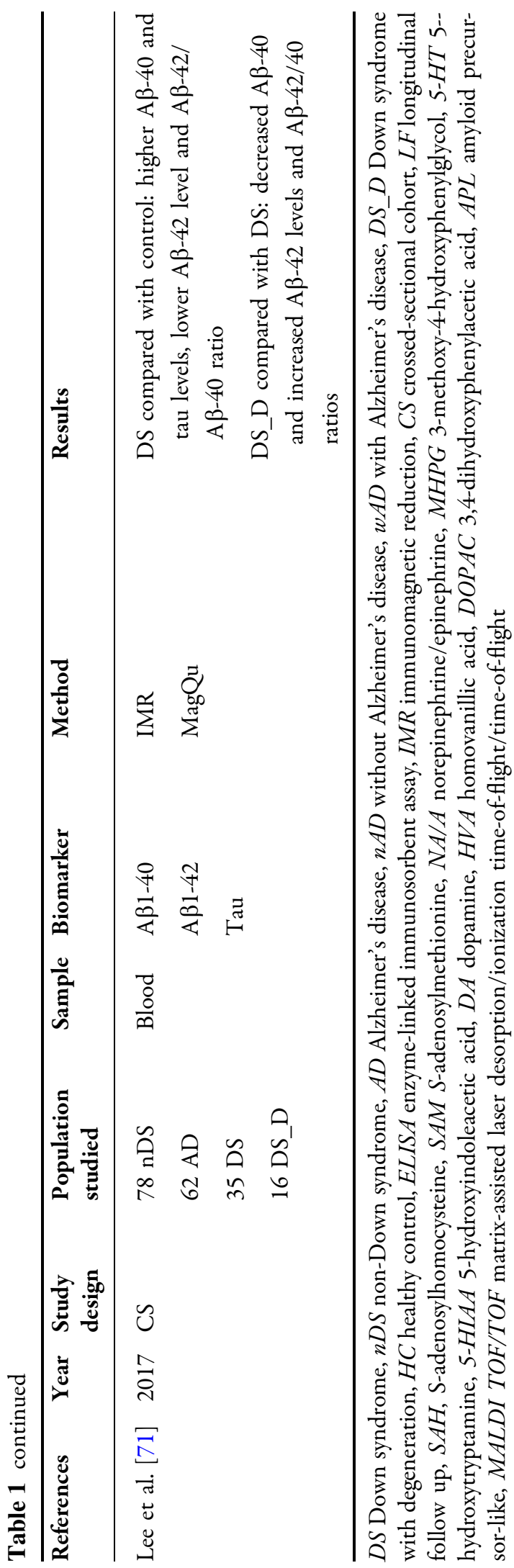

\section{CONCLUSION}

Given the underlying intellectual disability, AD in people with DS is usually difficult to diagnose. In addition to clinical presentations and imaging studies, biomarkers such as amyloid and tau aid in predicting AD in people with DS. Increasing numbers of biomarkers are being reported and may increase the prediction rate in early diagnosis.

\section{ACKNOWLEDGEMENTS}

No funding or sponsorship was received for this study or publication of this article. All named authors meet the International Committee of Medical Journal Editors (ICMJE) criteria for authorship for this manuscript, take responsibility for the integrity of the work as a whole, and have given final approval for the version to be published.

Disclosures. Ni-Chung Lee, Yin-Hsiu Chien and Wuh-Liang Hwu have nothing to disclose.

Compliance with Ethics Guidelines. This article is based on previously conducted studies and does not involve any new studies of human or animal subjects performed by any of the authors.

Data Availability. Data sharing is not applicable to this article as no datasets were generated or analyzed during the current study.

Open Access. This article is distributed under the terms of the Creative Commons Attribution-NonCommercial 4.0 International License (http://creativecommons.org/licenses/ by-nc/4.0/), which permits any noncommercial use, distribution, and reproduction in any medium, provided you give appropriate credit to the original author(s) and the source, provide a link to the Creative Commons license, and indicate if changes were made. 


\section{REFERENCES}

1. Lin SJ, Hu SC, Sheu SF, Ho JW, Chiou PC, Chao MC, et al. Anthropometric study on Down syndrome in Taiwan. Zhonghua Min Guo Xiao Er Ke Yi Xue Hui Za Zhi. 1991;32(3):158-64.

2. CDC. Improved national prevalence estimates for 18 selected major birth defects-United States, 1999-2001. MMWR Morb Mortal Wkly Rep. 2006;54:1301-5.

3. AAP issues guidelines on health supervision for children with Down syndrome. Am Fam Phys. 1994;50(3):695-7.

4. Bittles AH, Glasson EJ. Clinical, social, and ethical implications of changing life expectancy in Down syndrome. Dev Med Child Neurol. 2004;46(4):282-6.

5. Arbuzova S, Hutchin T, Cuckle H. Mitochondrial dysfunction and Down's syndrome. BioEssays. 2002;24(8):681-4.

6. Devenny DA, Wegiel J, Schupf N, Jenkins E, Zigman W, Krinsky-McHale SJ, et al. Dementia of the Alzheimer's type and accelerated aging in Down syndrome. Sci Aging Knowl Environ. 2005;2005(14):dn1.

7. Online Mendelian Inheritance in Man [Internet]. Johns Hopkins University. 2006. Available from: http://www.ncbi.nlm.nih.gov/entrez/dispomim.cgi? id=190685. Accessed 25 Feb 2006

8. Willard RL. Thompson \& Thompson genetics in medicine. 6th ed. Philadelphia: Saunders; 2001. p. 157-79.

9. Zana M, Janka Z, Kalman J. Oxidative stress: a bridge between Down's syndrome and Alzheimer's disease. Neurobiol Aging. 2006;28:648-76.

10. Struwe F. Histopathologische Untersuchungen über Entstehung und Wesen der senilen Plaques. Z Gesamte Neurol Psychiatr. 1929;122:291-307.

11. Rumble B, Retallack R, Hilbich C, Simms G, Multhaup G, Martins R, et al. Amyloid A4 protein and its precursor in Down's syndrome and Alzheimer's disease. N Engl J Med. 1989;320(22):1446-52.

12. Head E, Lott IT, Wilcock DM, Lemere CA. Aging in Down syndrome and the development of Alzheimer's disease neuropathology. Curr Alzheimer Res. 2016;13(1):18-29.

13. Lemere CA, Blusztajn JK, Yamaguchi H, Wisniewski T, Saido TC, Selkoe DJ. Sequence of deposition of heterogeneous amyloid beta-peptides and APO E in
Down syndrome: implications for initial events in amyloid plaque formation. Neurobiol Dis. 1996;3(1):16-32.

14. Xue QS, Streit WJ. Microglial pathology in Down syndrome. Acta Neuropathol. 2011;122(4):455-66.

15. Cardenas AM, Ardiles AO, Barraza N, Baez-Matus X, Caviedes $P$. Role of tau protein in neuronal damage in Alzheimer's disease and Down syndrome. Arch Med Res. 2012;43(8):645-54.

16. Wiseman FK, Al-Janabi T, Hardy J, Karmiloff-Smith A, Nizetic D, Tybulewicz VL, et al. A genetic cause of Alzheimer disease: mechanistic insights from Down syndrome. Nat Rev Neurosci. 2015;16(9): 564-74.

17. Hartley D, Blumenthal T, Carrillo M, DiPaolo G, Esralew L, Gardiner K, et al. Down syndrome and Alzheimer's disease: common pathways, common goals. Alzheimers Dement. 2015;11(6):700-9.

18. Mao R, Zielke CL, Zielke HR, Pevsner J. Global up-regulation of chromosome 21 gene expression in the developing Down syndrome brain. Genomics. 2003;81(5):457-67.

19. Prasher VP, Farrer MJ, Kessling AM, Fisher EM, West RJ, Barber PC, et al. Molecular mapping of Alzheimer-type dementia in Down's syndrome. Ann Neurol. 1998;43(3):380-3.

20. Busciglio J, Pelsman A, Wong C, Pigino G, Yuan M, Mori $\mathrm{H}$, et al. Altered metabolism of the amyloid beta precursor protein is associated with mitochondrial dysfunction in Down's syndrome. Neuron. 2002;33(5):677-88.

21. Misonou H, Morishima-Kawashima M, Ihara Y. Oxidative stress induces intracellular accumulation of amyloid beta-protein (Abeta) in human neuroblastoma cells. Biochemistry. 2000;39(23):6951-9.

22. Paola D, Domenicotti C, Nitti M, Vitali A, Borghi R, Cottalasso D, et al. Oxidative stress induces increase in intracellular amyloid beta-protein production and selective activation of betaI and betaII PKCs in NT2 cells. Biochem Biophys Res Commun. 2000;268(2):642-6.

23. Braak H, Braak E. Neuropathological staging of Alzheimer-related changes. Acta Neuropathol. 1991;82:239-59.

24. Jones EL, Mok K, Hanney M, Harold D, Sims R, Williams J, et al. Evidence that PICALM affects age at onset of Alzheimer's dementia in Down syndrome. Neurobiol Aging. 2013;34(10):2441 e1-5.

25. Dorval V, Mazzella MJ, Mathews PM, Hay RT, Fraser PE. Modulation of Abeta generation by small 
ubiquitin-like modifiers does not require conjugation to target proteins. Biochem J. 2007;404(2):309-16.

26. Mok KY, Jones EL, Hanney M, Harold D, Sims R, Williams J, et al. Polymorphisms in BACE2 may affect the age of onset Alzheimer's dementia in Down syndrome. Neurobiol Aging. 2014;35(6):1513 e1-5.

27. Patel A, Rees SD, Kelly MA, Bain SC, Barnett AH, Thalitaya D, et al. Association of variants within APOE, SORL1, RUNX1, BACE1 and ALDH18A1 with dementia in Alzheimer's disease in subjects with Down syndrome. Neurosci Lett. 2011;487(2):144-8.

28. Ryoo SR, Cho HJ, Lee HW, Jeong HK, Radnaabazar C, Kim YS, et al. Dual-specificity tyrosine(Y)-phosphorylation regulated kinase $1 \mathrm{~A}$-mediated phosphorylation of amyloid precursor protein: evidence for a functional link between Down syndrome and Alzheimer's disease. J Neurochem. 2008;104(5):1333-44.

29. Lee JH, Chulikavit M, Pang D, Zigman WB, Silverman W, Schupf N. Association between genetic variants in sortilin-related receptor 1 (SORL1) and Alzheimer's disease in adults with Down syndrome. Neurosci Lett. 2007;425(2):105-9.

30. Wolvetang EW, Bradfield OM, Tymms M, Zavarsek S, Hatzistavrou T, Kola I, et al. The chromosome 21 transcription factor ETS2 transactivates the beta-APP promoter: implications for Down syndrome. Biochim Biophys Acta. 2003;1628(2):105-10.

31. Henriksen K, Byrjalsen I, Christiansen C, Karsdal MA. Relationship between serum levels of tau fragments and clinical progression of Alzheimer's disease. J Alzheimer's Dis. 2015;43(4):1331-41.

32. Alexander GE, Saunders AM, Szczepanik J, Strassburger TL, Pietrini P, Dani A, et al. Relation of age and apolipoprotein $\mathrm{E}$ to cognitive function in Down syndrome adults. NeuroReport. 1997;8(8):1835-40.

33. Chace C, Pang D, Weng C, Temkin A, Lax S, Silverman W, et al. Variants in CYP17 and CYP19 cytochrome $\mathrm{P} 450$ genes are associated with onset of Alzheimer's disease in women with down syndrome. J Alzheimer's Dis. 2012;28(3):601-12.

34. Prasher VP, Sajith SG, Rees SD, Patel A, Tewari S, Schupf N, et al. Significant effect of APOE epsilon 4 genotype on the risk of dementia in Alzheimer's disease and mortality in persons with Down syndrome. Int J Geriatr Psychiatry. 2008;23(11):1134-40.

35. Huang LY. Risk factors for dementia in Down syndrome. Taiwan: National Taiwan University; 2016.
36. Zhao Q, Lee JH, Pang D, Temkin A, Park N, Janicki $\mathrm{SC}$, et al. Estrogen receptor-Beta variants are associated with increased risk of Alzheimer's disease in women with down syndrome. Dement Geriatr Cogn Disord. 2011;32(4):241-9.

37. Wilcock DM. Neuroinflammation in the aging down syndrome brain; lessons from Alzheimer's disease. Curr Gerontol Geriatr Res. 2012;2012:170276.

38. Wilcock DM, Hurban J, Helman AM, Sudduth TL, McCarty KL, Beckett TL, et al. Down syndrome individuals with Alzheimer's disease have a distinct neuroinflammatory phenotype compared to sporadic Alzheimer's disease. Neurobiol Aging. 2015;36(9):2468-74.

39. Griffiths-Jones S. The microRNA Registry. Nucl Acids Res. 2004;32(Database issue):D109-11.

40. Codocedo JF, Rios JA, Godoy JA, Inestrosa NC. Are microRNAs the molecular link between metabolic syndrome and Alzheimer's disease? Mol Neurobiol. 2016;53:2320-38.

41. Pan Y, Liu R, Terpstra E, Wang Y, Qiao F, Wang J, et al. Dysregulation and diagnostic potential of microRNA in Alzheimer's disease. J Alzheimer's Dis. 2015;49(1):1-12.

42. Dekker AD, Strydom A, Coppus AM, Nizetic D, Vermeiren Y, Naude PJ, et al. Behavioural and psychological symptoms of dementia in Down syndrome: early indicators of clinical Alzheimer's disease? Cortex. 2015;73:36-61.

43. Sabbagh M, Edgin J. Clinical assessment of cognitive decline in adults with Down syndrome. Curr Alzheimer Res. 2016;13(1):30-4.

44. Ball SL, Holland AJ, Treppner P, Watson PC, Huppert FA. Executive dysfunction and its association with personality and behaviour changes in the development of Alzheimer's disease in adults with Down syndrome and mild to moderate learning disabilities. Br J Clin Psychol. 2008;47(Pt 1):1-29.

45. Prasher V, Farooq A, Holder R. The Adaptive Behaviour Dementia Questionnaire (ABDQ): screening questionnaire for dementia in Alzheimer's disease in adults with Down syndrome. Res Dev Disabil. 2004;25(4):385-97.

46. Walsh DM, Doran E, Silverman W, Tournay A, Movsesyan N, Lott IT. Rapid assessment of cognitive function in down syndrome across intellectual level and dementia status. J Intellect Disabil Res. 2015;59:1071-9.

47. Gedye A. Dementia scale for Down syndrome: manual. Vancouver: Gedye Research and Consulting; 1995. 
48. Evenhuis HM. Further evaluation of the Dementia Questionnaire for Persons with Mental Retardation (DMR). J Intellect Disabil Res. 1996;40(Pt 4):369-73.

49. Deb S, Hare M, Prior L, Bhaumik S. Dementia screening questionnaire for individuals with intellectual disabilities. Br J Psychiatry J Mental Sci. 2007;190:440-4.

50. Vandenberghe R, Adamczuk K, Dupont P, Laere KV, Chetelat G. Amyloid PET in clinical practice: its place in the multidimensional space of Alzheimer's disease. Neuroimage Clin. 2013;2:497-511.

51. Sabbagh MN, Fleisher A, Chen K, Rogers J, Berk C, Reiman E, et al. Positron emission tomography and neuropathologic estimates of fibrillar amyloid-beta in a patient with Down syndrome and Alzheimer disease. Arch Neurol. 2011;68(11):1461-6.

52. Jennings D, Seibyl J, Sabbagh M, Lai F, Hopkins W, Bullich $S$, et al. Age dependence of brain beta-amyloid deposition in Down syndrome: an [18F]florbetaben PET study. Neurology. 2015;84(5):500-7.

53. Handen $\mathrm{BL}$, Cohen $\mathrm{AD}$, Channamalappa U, Bulova $\mathrm{P}$, Cannon SA, Cohen WI, et al. Imaging brain amyloid in nondemented young adults with Down syndrome using Pittsburgh compound B. Alzheimers Dement. 2012;8(6):496-501.

54. Annus T, Wilson LR, Hong YT, Acosta-Cabronero J, Fryer TD, Cardenas-Blanco A, et al. The pattern of amyloid accumulation in the brains of adults with Down syndrome. Alzheimers Dement. 2016;12(5):538-45.

55. Chiu MJ, Chen YF, Chen TF, Yang SY, Yang FP, Tseng TW, et al. Plasma tau as a window to the brain-negative associations with brain volume and memory function in mild cognitive impairment and early Alzheimer's disease. Hum Brain Mapp. 2014;35(7):3132-42.

56. Dani A, Pietrini P, Furey ML, McIntosh AR, Grady CL, Horwitz B, et al. Brain cognition and metabolism in Down syndrome adults in association with development of dementia. NeuroReport. 1996;7(18):2933-6.

57. Rafii MS, Wishnek H, Brewer JB, Donohue MC, Ness $\mathrm{S}$, Mobley WC, et al. The down syndrome biomarker initiative (DSBI) pilot: proof of concept for deep phenotyping of Alzheimer's disease biomarkers in down syndrome. Front Behav Neurosci. 2015;9:239.

58. Tapiola T, Soininen H, Pirttila T. CSF tau and Abeta42 levels in patients with Down's syndrome. Neurology. 2001;56(7):979-80.
59. Tamaoka A. Characterization of amyloid beta protein species in the plasma, cerebrospinal fluid and brains of patients with Alzheimer's disease. Nihon Ronen Igakkai zasshi Jpn J Geriatr. 1998;35(4):273-7.

60. Schupf N, Patel B, Silverman W, Zigman WB, Zhong $\mathrm{N}$, Tycko B, et al. Elevated plasma amyloid beta-peptide 1-42 and onset of dementia in adults with Down syndrome. Neurosci Lett. 2001;301(3):199-203.

61. Mehta PD, Mehta SP, Fedor B, Patrick BA, Emmerling $\mathrm{M}$, Dalton AJ. Plasma amyloid beta protein 1-42 levels are increased in old Down syndrome but not in young Down syndrome. Neurosci Lett. 2003;342(3):155-8.

62. Schupf N, Patel B, Pang D, Zigman WB, Silverman W, Mehta PD, et al. Elevated plasma beta-amyloid peptide Abeta(42) levels, incident dementia, and mortality in Down syndrome. Arch Neurol. 2007;64(7):1007-13.

63. Obeid R, Hubner U, Bodis M, Geisel J. Plasma amyloid beta 1-42 and DNA methylation pattern predict accelerated aging in young subjects with Down syndrome. Neuromol Med. 2016;18(4):593-601.

64. Hamlett ED, Goetzl EJ, Ledreux A, Vasilevko V, Boger HA, LaRosa A, et al. Neuronal exosomes reveal Alzheimer's disease biomarkers in Down syndrome. Alzheimers Dement. 2016;13:541-9.

65. Coppus AM, Schuur M, Vergeer J, Janssens AC, Oostra BA, Verbeek MM, et al. Plasma beta amyloid and the risk of Alzheimer's disease in Down syndrome. Neurobiol Aging. 2012;33(9):1988-94.

66. Schupf N, Zigman WB, Tang MX, Pang D, Mayeux $\mathrm{R}$, Mehta $\mathrm{P}$, et al. Change in plasma Ass peptides and onset of dementia in adults with Down syndrome. Neurology. 2010;75(18):1639-44.

67. Prasher VP, Sajith SG, Mehta P, Zigman WB, Schupf N. Plasma beta-amyloid and duration of Alzheimer's disease in adults with Down syndrome. Int J Geriatr Psychiatry. 2010;25(2):202-7.

68. Jones EL, Hanney M, Francis PT, Ballard CG. Amyloid beta concentrations in older people with Down syndrome and dementia. Neurosci Lett. 2009;451(2):162-4.

69. Head E, Doran E, Nistor M, Hill M, Schmitt FA, Haier RJ, et al. Plasma amyloid-beta as a function of age, level of intellectual disability, and presence of dementia in Down syndrome. J Alzheimer's Dis. 2011;23(3):399-409. 
70. Matsuoka Y, Andrews HF, Becker AG, Gray AJ, Mehta PD, Sano MC, et al. The relationship of plasma Abeta levels to dementia in aging individuals with Down syndrome. Alzheimer Dis Assoc Disord. 2009;23(4):315-8.

71. Lee NC, Yang SY, Chieh JJ, Huang PT, Chang LM, Chiu YN, et al. Blood beta-amyloid and tau in Down syndrome: a comparison with Alzheimer's disease. Front Aging Neurosci. 2016;8:316.

72. Tamaoka A, Sekijima Y, Matsuno S, Tokuda T, Shoji S, Ikeda SI. Amyloid beta protein species in cerebrospinal fluid and in brain from patients with Down's syndrome. Ann Neurol. 1999;46(6):933.

73. Portelius E, Holtta M, Soininen H, Bjerke M, Zetterberg $\mathrm{H}$, Westerlund $\mathrm{A}$, et al. Altered cerebrospinal fluid levels of amyloid beta and amyloid precursor-like protein 1 peptides in Down's syndrome. Neuromol Med. 2014;16(2):510-6.

74. Portelius E, Soininen H, Andreasson U, Zetterberg $\mathrm{H}$, Persson R, Karlsson G, et al. Exploring Alzheimer molecular pathology in Down's syndrome cerebrospinal fluid. Neurodegener Dis. 2014;14(2):98-106.
75. Yang SY, Chieh JJ, Yang CC, Liao SH, Chen HH, Horng $\mathrm{HE}$, et al. Clinic applications in assaying ultra-low-concentration bio-markers using HTS SQUID-based AC magnetosusceptometer. IEEE Trans Appl Supercond. 2013;23:1600604.

76. Iulita MF, Ower A, Barone C, Pentz R, Gubert P, Romano C, et al. An inflammatory and trophic disconnect biomarker profile revealed in Down syndrome plasma: relation to cognitive decline and longitudinal evaluation. Alzheimers Dement. 2016;12(11):1132-48.

77. Dekker AD, Coppus AM, Vermeiren Y, Aerts T, van Duijn CM, Kremer BP, et al. Serum MHPG strongly predicts conversion to Alzheimer's disease in behaviorally characterized subjects with Down syndrome. J Alzheimer's Dis. 2015;43(3):871-91.

78. Jenkins EC, Ye L, Krinsky-McHale SJ, Zigman WB, Schupf N, Silverman WP. Telomere longitudinal shortening as a biomarker for dementia status of adults with Down syndrome. Am J Med Genet B. 2016;171B(2):169-74. 